\title{
Nutrition Consultation and Egg White Extras at the Knowledge and Albumin Level Pulmonary Tuberculosis (Tb) Patients in the Irna Room, RSUD Dr. R. Soedarsono, Pasuruan City
}

\author{
Putri Merina ${ }^{1)}$, Nur Rahman ${ }^{2 *}$ and Sutomo Rum Teguh Kaswari ${ }^{2)}$ \\ 1) Alumni of the D-IV Study Program in the Field of Nutrition, Department of Nutrition, Politeknik \\ Kesehatan Kemenkes Malang \\ ${ }^{2)}$ Lecturer of the D-IV Nutrition Study Program, Department of Nutrition, Politeknik Kesehatan \\ Kemenkes Malang \\ E - mail : rahmancahaya@yahoo.com²*
}

\begin{abstract}
Tuberculosis (TB) is a lung infection characterized by pulmonary infiltrates and caseous granuloma formation, fibrosis and cavity. Extra egg white administration can increase serum albumin levels by an average of $1.13 \mathrm{~g} / \mathrm{dL}$. Nutrition counseling is very important given to increase knowledge and change attitudes or behaviors of pulmonary TB patients. The purpose of this study was to determine the effect of giving nutritional counseling and extra egg white to the knowledge and levels of albumin in pulmonary tuberculosis (TB) patients in the IRNA room of the RSUD $d r$. R. Soedarsono, Pasuruan city. This research is a quasi-experimental study (quasi experimental) with the research design used is the Desaign Group Pretest-Posttest Control. From the Wilcoxon statistical test the Asymp. Sig value is obtained. (2-tailed) of $0.001<0.05$, so Ho is accepted as meaning there are differences in the level of knowledge before and after obtaining nutritional counseling and the value of Asymp.Sig is also obtained. (2-tailed) of 0.001 $<0.05$, then Ho is accepted by means of differences in albumin levels in the treatment group. Conclusion: There is an effect of nutritional counseling on the knowledge of control and treatment respondents before and after being given nutritional counseling. There was a difference (increase) in pre and post albumin levels given extra white egg in the treatment group with an average increase of $0.21 \mathrm{~g} / \mathrm{dl}$.
\end{abstract}

Keywords: nutritional counseling, extra egg white, knowledge, albumin

\section{INTRODUCTION}

Tuberculosis (TB) is a pulmonary infection characterized by pulmonary infiltrates and the formation of caseous granulomas, fibrosis, and cavities. In 2013 the prevalence of TB cases was almost 9 million TB cases and 1.5 million TB deaths and 360,000 deaths with positive human immunodeficiency virus (HIV) (Simbolon, 2016). In 2013 there were an estimated 3.3 million cases of TB and 51,000 deaths in women. And there were 550,000 cases of TB and 80,000 deaths in children. Indonesia is the fifth country with the highest number of pulmonary TB patients in the world. The prevalence of the Indonesian population diagnosed with pulmonary TB in 2013 was $0.4 \%$. Based on population characteristics, the prevalence of pulmonary TB tends to increase with increasing age, low education and not working (Prastowo, 2016).

The nutritional status of the patient can be measured by calculating the Body Mass Index (BMI) and checking albumin levels. Albumin can be used as a classic indicator of malnutrition. An albumin level of less than $3.0 \mathrm{~g} / \mathrm{dl}$ indicates a worse prognosis in the presence of malnutrition. Low albumin levels are found in malnutrition due to malabsorption, namely incomplete absorption of food from the digestive tract (small intestine) 
into the bloodstream which causes malnutrition, as occurs in pulmonary tuberculosis (Wokas, et al. 2015). One of the factors that influence the incidence of pulmonary TB is nutritional status. Poor nutritional status will increase the risk of TB disease, otherwise pulmonary TB disease can affect the nutritional status of patients (Dias, et al. 2015). Increased levels of albumin is very important for patients with pulmonary $\mathrm{TB}$, in addition to improving the nutritional status of albumin in the body, it will also replace damaged body cells eaten by the TB virus and will become antibodies in the body of people with pulmonary $\mathrm{TB}$, as an anti-inflammatory and as an antioxidant. A preliminary study conducted on TB patients with hypoalbumin at Prof. Hospital. Dr. Margono Soekarji Purwokerto showed that the addition of egg whites can increase serum albumin levels by an average of $1.13 \mathrm{~g} / \mathrm{dL}$ (Prastowo, 2016).

The important thing besides increasing albumin levels to improve the nutritional status of pulmonary TB patients is nutritional counseling. Nutrition education is very important to be given to increase knowledge and change attitudes or behavior of pulmonary TB patients. Nutrition counseling is given to help understand the knowledge of balanced nutrition in pulmonary TB patients and provide motivation to recover and improve compliance in carrying out treatment or other medical therapies. Nutrition counseling is easy and effective in stabilizing the nutritional status of pulmonary TB patients (Cornelia, et al. 2013). There is a significant difference between knowledge about medication adherence in pulmonary TB patients before and after receiving nutrition counseling, there is a significant difference in attitudes about medication adherence in pulmonary TB patients before and after receiving counseling (Loriana, et al. 2012).

RSUD dr. R. Soedarsono, Pasuruan City is a type $\mathrm{C}$ government hospital and the only government hospital in Pasuruan City. RSUD dr. R. Soedarsono, Pasuruan City has a bed capacity (TT) of 259 beds with a Bed Occupancy Rate (BOR) of $64.35 \%$. Pulmonary Tuberculosis (TB) is included in the 10 biggest diseases or can be said to be the disease with the tenth highest number of patients at RSUD dr. R. Soedarsono, Pasuruan City with a number of 300-500 patients per year with a total of 4.1 percent of patients being treated until the patient's condition improves from before.

Based on the description above, the researchers are interested in conducting further research regarding the provision of nutritional counseling and the addition of egg whites on knowledge and albumin levels in pulmonary tuberculosis (TB) patients in the IRNA room of RSUD dr. R. Soedarsono, Pasuruan City.

\section{METHODS}

This research is a quasi-experimental research (quasi-experimental). While the research design used is the Pretest-Posttest Control Group Design. The sample in this study were all pulmonary tuberculosis (TB) patients who were hospitalized in the IRNA room of RSUD dr. R. Soedarsono Pasuruan City. Data were analyzed using Wilcoxon statistical test.

\section{RESULTS AND DISCUSSION}

1. Characteristics of respondents

Table 1. Distribution of Respondents by Gender

\begin{tabular}{ccccccc}
\hline Gender & \multicolumn{2}{c}{ Control } & \multicolumn{2}{c}{ Treatment } & \multicolumn{2}{c}{ Total } \\
& $\mathbf{n}$ & $\mathbf{\%}$ & $\mathbf{n}$ & $\mathbf{\%}$ & $\mathbf{n}$ & $\mathbf{\%}$ \\
Man & 8 & 53,3 & 14 & 93,3 & 22 & 73,3 \\
Woman & 7 & 46,7 & 1 & 6,7 & 8 & 26,7 \\
Total & $\mathbf{1 5}$ & $\mathbf{1 0 0}$ & $\mathbf{1 5}$ & $\mathbf{1 0 0}$ & $\mathbf{3 0}$ & $\mathbf{1 0 0}$ \\
\hline Processed data, 2018 & & & &
\end{tabular}

Table 2. Distribution of Respondents by Age

\begin{tabular}{|c|c|c|c|c|c|c|}
\hline \multirow[t]{2}{*}{ Gender } & \multicolumn{2}{|c|}{$\begin{array}{l}\text { Control } \\
\text { Group }\end{array}$} & \multicolumn{2}{|c|}{$\begin{array}{c}\text { Treatment } \\
\text { Group }\end{array}$} & \multicolumn{2}{|c|}{ Total } \\
\hline & $\mathbf{n}$ & $\%$ & $\mathbf{n}$ & $\%$ & $\mathbf{n}$ & $\%$ \\
\hline $\begin{array}{c}20-30 \\
\text { years } \\
\text { old }\end{array}$ & 1 & 6,7 & 0 & 0 & 1 & 3,3 \\
\hline $\begin{array}{c}31-40 \\
\text { years } \\
\text { old }\end{array}$ & 1 & 6,7 & 1 & 6,7 & 2 & 6,7 \\
\hline $\begin{array}{c}41-50 \\
\text { years } \\
\text { old }\end{array}$ & 2 & 13,3 & 3 & 20 & 5 & 16,7 \\
\hline $\begin{array}{c}51-60 \\
\text { years } \\
\text { old } \\
>60\end{array}$ & 7 & 46,7 & 7 & 46,7 & 14 & 46,7 \\
\hline $\begin{array}{c}\text { years } \\
\text { old }\end{array}$ & 4 & 26,7 & 4 & 26,7 & 8 & 26,7 \\
\hline Total & 15 & 100 & 15 & 100 & 30 & 100 \\
\hline
\end{tabular}

Processed data, 2018 
Table 3. Distribution of Respondents by 5. The results of the Wilcoxon statistical test Education Level

\begin{tabular}{|c|c|c|c|c|c|c|}
\hline \multirow{2}{*}{$\begin{array}{l}\text { Level of } \\
\text { Education }\end{array}$} & \multicolumn{2}{|c|}{$\begin{array}{l}\text { Control } \\
\text { Group }\end{array}$} & \multicolumn{2}{|c|}{$\begin{array}{l}\text { Treatment } \\
\text { Group }\end{array}$} & \multirow{2}{*}{\multicolumn{2}{|c|}{$\begin{array}{l}\text { Pbtained the Asymp.Sig value. (2-tailed) of } \\
0.490>0.05 \text {, then Ho is rejected, meaning that } \\
\text { n there\%s no difference in albumin levels in the }\end{array}$}} \\
\hline & $\mathbf{n}$ & $\%$ & $\mathbf{n}$ & $\%$ & & \\
\hline $\begin{array}{l}\text { Elementary } \\
\text { School/ }\end{array}$ & 4 & 26,7 & 6 & 40 & 10 & ${ }_{33,3}^{\text {control group. }}$ \\
\hline $\begin{array}{l}\text { Equivalent } \\
\text { Junior High }\end{array}$ & & & & & & $\begin{array}{l}\text { The results of the Wilcoxon statistical test } \\
\text { analysis using SPSS in the treatment group }\end{array}$ \\
\hline $\begin{array}{l}\text { School / } \\
\text { Equivalent }\end{array}$ & 5 & 33,3 & 1 & 6,7 & 6 & $\begin{array}{l}\text { obtained the Asymp.Sig value. ( } 2 \text {-tailed) of } \\
0.001<0.05 \text {, Ho is accepted, which means }\end{array}$ \\
\hline $\begin{array}{l}\text { Senior High } \\
\text { School / } \\
\text { Equivalent }\end{array}$ & 6 & 40 & 8 & 53,3 & 14 & $\begin{array}{l}\text { that there are differences in albumin levels in } \\
\text { the freatment group before and after getting }\end{array}$ \\
\hline Total & 15 & 100 & 15 & 100 & 30 & gnal egg whites for 3 consecutive days. \\
\hline
\end{tabular}

Processed data, 2018

2. Respondent's Level of Knowledge

Table 4. Distribution of knowledge level of respondents before and after receiving nutrition counseling

\begin{tabular}{|c|c|c|c|c|c|c|c|c|}
\hline \multirow{4}{*}{$\begin{array}{l}\text { Level of } \\
\text { Education }\end{array}$} & \multicolumn{4}{|c|}{ Control } & \multicolumn{4}{|c|}{ Treatment } \\
\hline & \multirow{2}{*}{\multicolumn{2}{|c|}{$\begin{array}{l}\text { Pre } \\
\text { test }\end{array}$}} & \multirow{2}{*}{\multicolumn{2}{|c|}{$\begin{array}{c}\text { Post } \\
\text { test }\end{array}$}} & \multirow{2}{*}{\multicolumn{2}{|c|}{$\begin{array}{l}\text { Pre } \\
\text { test }\end{array}$}} & \multirow{2}{*}{\multicolumn{2}{|c|}{$\begin{array}{c}\text { Post } \\
\text { test }\end{array}$}} \\
\hline & & & & & & & & \\
\hline & $\mathrm{n}$ & $\%$ & $\mathrm{n}$ & $\%$ & $\mathrm{n}$ & $\%$ & $\mathrm{n}$ & $\%$ \\
\hline & 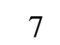 & 46,7 & 0 & 0 & 8 & 53,3 & 0 & 0 \\
\hline Enou & 8 & 53,3 & 10 & 66,7 & 7 & 46,7 & 9 & 60 \\
\hline & 0 & 0 & 5 & 33,3 & 0 & 0 & 6 & 40 \\
\hline Tota & 15 & 100 & 15 & 100 & 15 & 100 & 15 & 100 \\
\hline
\end{tabular}

Processed data, 2018

3. Respondent's Albumin Level

Table 5. Distribution of Laboratory Results of Respondents' Albumin Levels Before and After Treatment

\begin{tabular}{ccccc}
\hline $\begin{array}{c}\text { Albumin } \\
\text { level }\end{array}$ & \multicolumn{2}{c}{$\begin{array}{c}\text { Control } \\
\text { Group } \\
\text { (pre-post) }\end{array}$} & \multicolumn{2}{c}{$\begin{array}{c}\text { Treatment } \\
\text { Group } \\
\text { (pre-post) }\end{array}$} \\
Decrease & 8 & 53 & 0 & 0 \\
Permanent & 1 & 6,7 & 0 & 0 \\
Increase & 6 & 40 & 15 & 100 \\
Total & $\mathbf{1 5}$ & $\mathbf{1 0 0}$ & $\mathbf{1 5}$ & $\mathbf{1 0 0}$ \\
\hline
\end{tabular}

Processed data, 2018

4. The results of the Wilcoxon statistical test analysis using SPSS in the control group and the treatment group obtained the Asymp.Sig value. (2-tailed) of $0.001<0.05$ then $\mathrm{Ho}$ is accepted, meaning that there are differences in the level of knowledge before and after receiving nutrition counseling.
1. Characteristics of respondents

Based on Table 1. it is known that the control group of respondents with male sex is $53.3 \%$ and female is $46.7 \%$. While in the treatment group, respondents were $93.3 \%$ male and $6.7 \%$ female. This is related to the number of male pulmonary TB patients treated at RSUD dr. R. Soedarsono Pasuruan City is more dominant in the female gender. In general, the average gender of the respondents in this study was $73.3 \%$ of respondents with pulmonary TB were male, while only $26.7 \%$ were female. Respondents with the most male sex were obtained from the treatment group while the most female sex was obtained from the control group. This study is in accordance with the research of Prastowo, et al (2016) which stated that most of the pulmonary TB patients sampled were male. The data of this study is also directly proportional to the data of patients in RSUD dr. R. Soedarsono Pasuruan City related to the gender of pulmonary TB patients being treated. The data collection or entry section explained that every month pulmonary $\mathrm{TB}$ patients undergoing treatment at RSUD dr. R. Soedarsono Pasuruan City with more males than females. According to Manurung, et al (2009) stated that the sex of male pulmonary TB patients was almost twice that of female pulmonary $\mathrm{TB}$ patients, namely $42.34 \%$. Pulmonary TB is more common in men than women because most men have a smoking 
habit, which increases the risk of developing pulmonary TB.

Based on Table 2. It is known that the control group of respondents with the age group of 20-30 years and $31-40$ years is $6.7 \%$, the $41-5$ year age group is $13.3 \%$, the $51-60$ age group is $13.3 \% .46 .7 \%$ and the age group of 0.60 years by $26.7 \%$. While the treatment group of respondents with the age group of 2030 years was $0 \%$, the age group 31-40 years was $6.7 \%$, the age group 41-50 years was $20 \%$, the 51-60 year age group was $46.7 \%$ and age 0.60 years by $26.7 \%$. In general, the average age group with the most pulmonary TB disease ranges from 51-60 years. In the control group, the most pulmonary TB patients were in the 51-60 years age group by $46.7 \%$ and the lowest pulmonary TB patients in the 20-30 years and 31-40 years age groups respectively $6.7 \%$. While in the treatment group, the most pulmonary TB patients were in the 51-60 years age group by $46.7 \%$ and the lowest pulmonary TB patients in the 31-40 years age group at $6.7 \%$. This study is in accordance with the research of Loriana, et al (2012) which states that the age of the respondents who are used as research samples are partly in the 41-60 year age group. Another study that is in accordance with this research is the research of Prastowo, et al (2016) which also states that the age of the respondents who became the largest research sample was in the 50-60 year age group. The data of this study is also directly proportional to the results of the recapitulation of the Medical Record Installation of RSUD dr. R. Soedarsono, Pasuruan City, related to the age of patients with a medical diagnosis of pulmonary TB, where the male and female sexes were mostly 50-60 years old. According to Manurung, et al (2009) stated that in Indonesia $75 \%$ of pulmonary TB patients are in the productive age group, namely 15-50 years. Where in the productive age humans do more activities or activities. At the productive age the activity is very high and the environmental conditions will be more supportive. An unhealthy environment and the type of work that is too heavy or even associated with the risk of pulmonary TB are the main causes of the development of pulmonary TB.

Based on Table 3. the education level of respondents in the control group, respondents with an elementary education level/equivalent is $26.7 \%$, with a junior high school education level/equivalent of $33.3 \%$ and a high school education level of $40 \%$. Meanwhile, in the treatment group, the results obtained were $40 \%$ for the respondents' education level of SD/Equivalent, $6.7 \%$ for the education level of SMP/Equivalent and $53.3 \%$ for the education level of SMA/Equivalent. This shows the distribution of respondents with pulmonary TB at various levels of education. In general, the education level of respondents who suffer from pulmonary $\mathrm{TB}$ is known to be $33.3 \%$ elementary school/equivalent, $20 \%$ junior high school/equivalent and $46.7 \%$ high school/equivalent. The highest education level in the control group was at the high school level/equivalent and the lowest education level was elementary school/equivalent. In contrast to the control group, in the treatment group the lowest education level was at the junior high school/equivalent level and the largest was the same as the control group, namely at the high school/equivalent level. This study is not in accordance with the research conducted by Dias, et al (2015) which stated that the highest education level of the respondents sampled was SD/equivalent. Meanwhile, in this study, the largest respondent's education level was SMA/equivalent. According to Manurung, et al (2009) states that a person's level of education will affect a person's knowledge, including about a house that meets health requirements and knowledge about pulmonary TB disease so that with sufficient knowledge, a person will try to have a clean and healthy place to live. healthy lifestyle. In addition, a person's level of education will affect the type of work. The better the level of formal education in the community will indirectly reduce the morbidity and mortality rate because with a good level of education it is able to absorb information and increase public awareness to live healthier and 
participate actively in maintaining their health.

2. Respondent's level of knowledge

Based on Table 4. the level of knowledge of respondents in the control group before receiving nutrition counseling in the less category was $46.7 \%$, the sufficient category was $53.3 \%$ and the good category was $0 \%$. For the level of knowledge after receiving nutrition counseling on the second day of observation, the level of knowledge of the respondents in the less category was $0 \%$, with the moderate category increasing by $66.7 \%$ and in the good category by $33.3 \%$. While the level of knowledge of respondents in the treatment group before receiving nutrition counseling was in the less category of $53.3 \%$, with a sufficient category of $46.7 \%$ and in the good category of $0 \%$. For the level of knowledge of respondents in the control group after receiving nutrition counseling on the second day of observation, the level of knowledge in the less category was $0 \%$, with the sufficient category increasing by $60 \%$ and in the good category by $40 \%$. This is related to the need for nutritional counseling in patients with a medical diagnosis of pulmonary TB to increase appetite even in a state of nausea to maintain nutritional status and improve dietary compliance as well as treatment and prevention of pulmonary TB. In general, the average level of knowledge of respondents before receiving nutrition counseling was $46.7 \%$ in the poor category and $53.3 \%$ in the sufficient category, for the good category $0 \%$. While the level of knowledge of respondents after receiving nutrition counseling on average increased by $0 \%$ in the less category where before nutrition counseling there were still some respondents with the category of poor knowledge level. For the medium category it increased by $66.7 \%$ and for the good category it increased by $33.3 \%$ from before getting nutrition counseling. The increase in the percentage of respondents' knowledge level is supported by several factors, including support from family, support from fellow respondents and the patient's ability to remember the counseling that has been given by the researcher This happened because the respondent's room was in the form of a semi-ward (1 large room containing 4-6 patients). When researchers conducted nutrition counseling, many respondents were accompanied by their families, be they their wives, husbands, children, even nephews and grandchildren. Some of these factors are also the effect of increasing the percentage of respondents' knowledge levels. This study is in accordance with Kurnia's research, 2014 where in this study there were significant differences in knowledge about medication adherence in pulmonary TB patients after and before receiving nutrition counseling. Another study that is in accordance with this research is the research of Loriana, et al (2012) which concludes that there are differences in the level of knowledge of respondents before and after receiving nutrition counseling. According to Supariasa, 2012 states that nutrition counseling is a broad-dimensional process to change people's behavior so that good eating habits can be applied in everyday life. Saleem (2012) in Kurnia, 2014 also stated that nutritional counseling is easy and very effective in stabilizing the nutritional status of pulmonary TB patients. Based on direct interviews with respondents, both control and treatment groups, it was found that after receiving nutrition counseling and motivation to increase food intake, diet management and TB treatment, respondents became more motivated to increase food intake and additional egg whites. given as an alternative to increase albumin levels. In addition, respondents also stated that after being given nutrition counseling, respondents became more aware of how to prevent $\mathrm{TB}$ and treat $\mathrm{TB}$ patients until the patient recovered. According to Kurnia, 2014 states that although some respondents have received nutrition counseling, sometimes they still do not understand what we mean, for that we as personnel who will provide nutrition counseling must use clear material and use sentences or language that is easily understood by respondents. 
3. Respondent's albumin level

Based on Table 5, it is known that in the control group, pre and post albumin levels varied. Albumin levels decreased by 53\%, which remained at $6.7 \%$ and increased by $40 \%$. Meanwhile, in the treatment group that was given additional egg white for 3 days, albumin levels decreased and remained $0 \%$ and albumin levels increased by $100 \%$. That is, respondents with the treatment group experienced an increase in albumin levels after being given additional egg white for 3 consecutive days as much as $250 \mathrm{~g} /$ day. This is related to the need for additional egg whites and the motivation to consume them for patients with pulmonary $\mathrm{TB}$ as an alternative to improving nutritional status. In general, the average albumin levels of respondents before and after the control group and the treatment group were different. In the control group the average increase in albumin levels was 0.28 $\mathrm{g} / \mathrm{dl}$ and the average decrease in albumin levels was $0.29 \mathrm{~g} / \mathrm{dl}$. While the pre- and posttreatment groups for 3 days of monitoring all experienced an increase with an average increase of $0.21 \mathrm{~g} / \mathrm{dl}$. According to Muchtadi, 2009 that the most protein-containing food sources come from animal foods, such as eggs, milk, meat, poultry, fish and shellfish. This study is in accordance with research conducted by Prastowo, et al (2014) which states that there are differences in albumin levels in the two groups (control and treatment groups). In the control group, all study subjects experienced an increase in albumin levels with an average increase of $0.70 \mathrm{~g} / \mathrm{dl}$. It is known that albumin in eggs (ovoalbumin) is found in the white part of the egg more than the yolk. White chicken eggs in every $100 \mathrm{~g}$ contain an average of $10.5 \mathrm{~g}$ protein, $95 \%$ of which is albumin or $9.83 \mathrm{~g}$ (Muchtadi, 2009). According to Prastowo, 2014 stated that egg white is effective for increasing albumin levels in pulmonary TB patients with hypoalbumin. Increased albumin can reduce patient complaints such as shortness of breath and cough. Based on interviews with the treatment group, it was found that after getting additional egg whites for 3 consecutive days, namely $250 \mathrm{~g} / \mathrm{day}$, respondents' complaints such as coughing and shortness of breath decreased. Supported by the patient's physical condition getting better, on the first day the patient was treated with complaints of shortness of breath using a spontaneous $\mathrm{O} 2$ device on the third day the patient no longer used it.

\section{CONCLUSIONS}

Based on Wilcoxon statistical analysis of nutrition counseling on the level of knowledge of respondents there is a significant relationship with the value of Asymp.Sig. of $0.001<0.05$, which means that there is an effect of nutritional counseling on the level of knowledge of respondents, and based on Wilcoxon statistical analysis of additional egg white on respondents' albumin levels there is a significant relationship with the Asymp.Sig value. of $0.001<0.05$, which means that there is an effect of giving additional egg whites to the respondents' albumin levels.

\section{REFERENCES}

Almatsier, Sunita. 2009. Prinsip Dasar Ilmu Gizi. Gramedia Pustaka Utama, Jakarta

Almatsier, Sunita. 2004. Penuntun Diet. Gramedia Pustaka Utama, Jakarta

Cornelia, Sumedi, E., Anwar, I., Ramayulis, R., Iwaningsih, S., Kresnawan, T., Nurlita H. 2013. Konseling Gizi. Penebar Plus, Jakarta

Denisica, S.N. 2015. Malnutrisi dan Anemia Pada Penderita Tuberkulosis Paru. Majority,4 (8) : $29-36$

Dias, F.D., Wirjatmadi, B., Adriani, M. 2015. Peran Zinc Sulphate dan Omega 3 Terhadap Peningkatan Kadar Albumin Pada Penderita Tuberkulosis Paru Di RS Surabaya Tahun 2015. Jurnal Ilmiah Kedokteran,4 (1) : 51 - 61

Hasan, I dan Anggraeni T,I. 2008. Peran Albumin dalam Penatalaksanaan Sirosis Hati. MEDICINUS, Volume 21, Nomor 2

Huda, N.S., Siswati, T. 2015. Pemberian Ekstra Jus Putih Telur Terhadap Kadar Albumin dan Hb Pada Penderita Hipoalbuminemia. Jurnal Gizi Klinik Indonesia,12 (2) : 54 - 61 
Komang, I.A.M., Putu, N.A., Guzti, I.A.A.W., Agung, A.A.K. 2015. Dampak Pemberian Putih Telor Terhadap Peningkatan Kadar Albumin Penderita Hipoalbuminemia di BRSU Tabanan Provinsi Bali. Jurnal Skala Husada,12 (2) : 178 - 181

Kurnia, S.A. 2014. Pengaruh Konseling Gizi Terhadap Pengetahuan Gizi Pada Penderita TB Paru Di Balai Besar Kesehatan Paru Masyarakat (BBKPM) Surakarta. Skripsi, FIK - UMM, Surakarta

Lawrence, T.M., Stephen, M.J. dan Maxine, P.A. 2002. Diagnosis dan Terapi Kedokteran (Penyakit Dalam). Salemba Medika, Jakarta

Lean, M.E.J. 2013. Ilmu Pangan, Gizi dan Kesehatan. Pustaka Pelajar, Yogyakarta

Loriana, R, dkk. 2012. Efek Konseling Terhadap Pengetahuan, Sikap dan Kepatuhan Berobat Penderita Tuberkulosis Paru di Wilayah Kerja Dinas Kesehatan Kota Samarinda. Jurnal Ilmiah-Poltekkes Kota Samarinda

Manurung, S., Suratun, Krisanty, P., Putu, E.N.L. 2009. Asuhan Keperawatan Gangguan Sistim Pernafasan Akibat Infeksi. Trans Info Media, Jakarta

Muchtadi, T., Sugiyono. dan Ayustaningwarno, F. 2011. Ilmu Pengetahuan Bahan Pangan. Alvabeta, Bandung

Muchtadi, T. 2009. Prinsip Teknologi Pangan Sumber Protein. Alvabeta, Bandung

Mulyanton, H. 2014. Hubungan Lima Indikator Perilaku Hidub Bersih Dan Sehat Dengan Tuberkulosis Multidrug Resistant. Jurnal Berkala Epidemiologi, 2 (3) : 355 - 367

Nuraini, F. 2017. Gambaran Profil Penderita Tuberkolosis Paru Di RSUP Dr Soeradji Tirtonegoro Klaten. Skripsi, FK - UMM, Surakarta

Notoadmodjo, Soekidjo. 2003. Pendidikan dan Perilaku Kesehatan. Rineka Cipta: Jakarta

Notoadmodjo, Soekidjo. 2007. Kesehatan Masyarakat Ilmu dan Seni. Rineka Cipta: Jakarta

Notoadmodjo, Soekidjo. 2005. Metodologi Penelitian Kesehatan. Rineka Cipta: Jakarta
Pearce, E.C. 2011. Anatomi dan Fisiologi Untuk Paramedis. Gramedia Pustaka Utama, Jakarta

Prastowo, A., Lestariana, W., Nurdjanah, S. 2014. Efektifitas Pemberian Ekstra Putih Telur Terhadap Peningkatan Kadar Albumin Pada Pasien Tuberkolosis Dengan Hipoalbumin. Mandala of Health, 10 (3) : 111 - 118

Prasetya, Z.A. 2015. Hubungan Antara Dukungan Sosial Keluarga Dengan Perilaku Pencegahan Penularan Tuberkolosis Paru Di Wilayah Kerja Puskesmas Purwodadi. Skripsi, FK - UNDIP, Semarang

Putra, I.P., Burhan ,E., Tambunan, V. 2012. Malnutrisi dan Tuberkulosis. J Inso Med Assoc, volume 10 (nomor 3) : hal 230 - 236

Ruswanta, D.F. 2016. Pengaruh Pendidikan Gizi Terhadap Pengetahuan, Sikap, Keterampilan Keluarga Serta Tingkat Konsumsi Energi dan Protein Pasien Penyakit Ginjal Kronik Dengan Hemodialisis di Rumah Sakit Tentara Tk II $d r$ Soepraoen Malang. Skripsi, Poltekkes Kemenkes Malang, Malang

Rab, T. 2010. Ilmu Penyakit Paru. Trans Info Media, Jakarta

Sadjaja, Atmaria. 2010. Kamus Gizi. Kompas, Jakarta

Simbolon, H.T., Lombo, J.C. dan Wongkar, M.C.P. 2016. Hubungan Indeks Massa Tubuh Dengan Kadar Albumin Pada Pasien Tuberkolosis Paru. Jurnal e-Clinic, 4 (2)

Slamet. 2016. Hubungan Kadar Albumin Pada Penderita Penyakit Tuberkolosis Paru Selama Masa Pengobatan Di Unit Pengobatan Penyakit Paru (UP4) Pontianak. Sanitarian, 8 (3) : 375 - 379

Sugiyono. 2011. Metode Penelitian Kuantitatif dan Kualitatif DAN R\&D. Alfabeta, cetakan ke 14, Bandung

Sulistya, H.K, dkk. 2014. Hubungan Asupan Protein dan Kadar Albumin Pasien Kanker di Rumah Sakit Roemani Muhammadiyah Semarang. Jurnal Gizi Universitas Muhammadiyah Semarang, 3 (2) : 43 - 52 
Journal of Local Therapy

Vol. 1, No. 1, February 2022

p-ISSN: 2809-3240; e-ISSN: 2810-0875

pp: 6 - 13

Sumarmi dan Duarsa, A.B.S. 2014. Analisis Hubungan Kondisi Fisik Rumah Dengan Kejadian TB Paru BTA Positif Di Puskesmas Kotabumi II, Bukit Kemuning Dan Ulak Rengas Kab. Lampung Utara Tahun 2012. Jurnal Kedokteran Yarsi, 22 (2) : 82 - 101

Suharyo. 2013. Determinasi Penyakit Tuberkulosis di Daerah Pedesaan. Kesmas, 9 (1) : $85-91$

Supariasa, I.D.N. 2012. Pendidikan dan Konsultasi Gizi. EGC, Jakarta

Sutedjo, A.Y. 2007. Mengenal Penyakit Melalui Hasil Pemeriksaan Laboraturium. Amara Books, Yogyakarta

Vera, T.H., Rivolta, G.M.W., Olife, S. 2014.
Suplementasi Protein Ikan Gabus Sebagai Alternatif Dalam Penatalaksanaan Diet Pada Pasien Dengan Indikasi Hipoalbuminemia di RSUP Prof. Dr. R.D. Kandou Manado. GIZIDO

Wasesa, R.A.L., Wirjatmadi, B., Adriani, M. 2016. Tingkat Kecukupan Zat Gizi Makro dan Status Gizi Pasien Tuberkulosis Dengan Sputum BTA (+) dan Sputum BTA (-). Media Gizi Indonesia,11 (2) : $144-152$

Wokas, J.A.J., Wongkar, M.C.P. dan Surachmanto, E. 2015. Hubungan Antara Status Gizi, Sputum BTA Dengan Gambaran Rontgen Paru Pada Pasien Tuberkolosis. Jurnal e-Clinic, 3 (1) : 298 - 30 